\title{
Queen Elizabeth's Visit to Tilbury in 1588
}

T June and July 1588, just before the Spanish Armada sailed up 1 the English Channel, an army was assembled at West Tilbury, on the north bank of the Thames. The object was to ensure the defence of London, by blocking access thereto, both by road and by river, in the event of the Armada attempting to land a force, as was expected, in the estuary of the Thames.

It is well known that the queen visited Tilbury to review the troops assembled there, and that she addressed to them ('like another Boadicea', as Morant, the Essex historian says) a famous exhortation to valour. But no one has hitherto traced in any detail the events connected with the visit-probably because local knowledge is necessary in order to follow the somewhat slight contemporary accounts of what took place. Indeed, the preparations made on land for the defence of the country have been extremely little studied, though the preparations made for its defence by sea have been treated exhaustively.

The Armada, we must remember, after one false start and other delays, due chiefly to bad weather, set sail finally from Coruña on 12 July, under the duke of Medina-Sidonia. On the 20th, it was sighted near the western entrance to the Channel by the English fleet, which had put out from Plymouth, under Lord Howard of Effingham. As the Armada sailed up the Channel, it was engaged by the English fleet in a running fight, during which several of the largest Spanish ships were either captured or destroyed. The intention was to embark in Flanders a large army which the king of Spain had caused to be assembled there, under the duke of Parma, for the invasion of England. The army was, however, not quite ready, so the Armada put into Calais roadstead to await it. Here, on the 28th, its serious. troubles began ; for the English, sending in fire-ships, caused the Spanish ships to scatter in extreme panic and confusion. Many in so doing cut or slipped their cables, whereby they came afterwards to dire disaster, through being no longer able to anchor. Never again, in fact, was the Armada able to reform as an organized fleet. Most of the ships fled northwards, pursued and harassed by the 
English-'driven like a flock of sheep ', as Drake reported ; while others were wrecked or captured on the Flemish coast. The chase continued up the east coast of England as far north as the Tyne ; whence, on the 2nd August, the English fleet had to return, through lack of powder and shot, thus losing touch with the fleeing Armada, which disappeared to the northward-no one then knew whither.

The formation of the camp at Tilbury was a part only of the defensive measures taken on land. Early in June, when at last it had become obvious that the king of Spain seriously contemplated the invasion and conquest of England, and that the mighty fleet he had long had in preparation was intended solely for that purpose, energetic steps were taken all over England to organize forces in order to repel the invasion which seemed so imminent. Aske, a contemporary rhymster, says ${ }^{1}$ that the Queen

was not slack in must'ring of her men;

For, lesse than in the space of two whole moneths, She mustered had, out of all her shires,

A hundred thousand able fighting men.

The two months were June and July, during which the Privy Council was busy writing letters to the Lords-Lieutenant of Counties throughout England and Wales, giving instructions to them in reference to the raising and equipping of troops. ${ }^{2}$ Nor does Aske's statement as to the number raised seem to be exaggerated in any way; for, according to returns prepared at the time, the number was twice as great as he says. ${ }^{3}$

Stowe says that, as soon as the queen received certain news of the coming of the Spaniards, she 'forthwith settled all her land forces in warlike readinesse, but ordayned no more Campes then that at Tilbury'. This camp was, however, of great importance, and in it were assembled the best of the queen's troops: hence it came to be known as 'The Camp Royal'. 'There can be no doubt that, in establishing it at Tilbury, the queen acted upon the advice of her favourite the earl of Leicester, who appears from the very first to have been virtually in command of it. Probably, too, it was on his suggestion that, soon after the middle of July, about $\mathbf{8 7 0}$ horse soldiers had been ordered to assemble at

1 Elizabetha Triumphans, with a Declaration of the HAanner how her Excellency was entertained by her Souldyers into her Campe Royall, at Tilbery, in Essex. Printod by Thos. Orwin for Thos. Gubbin and Thos. Newman, London, 1588, 35 pp. 4to. (The whole effusion was roprinted verbatim in Nichol's Progresses, ii, pp. 545-82, 1823).

- So Acts of the Privy Courcil, xvi (1897).

- The returns (printed in Dodsley's Hist. of Spanish Armada, pp. 11-33, 1759, and in J. Bruce's Report on the Atrangements which uere made for the Internal Defence of these Kingdoms when Spain, by its Amada, projected the Invasion and Conquest of Englarid, p. 84, 1798) are arranged according to counties, and no general total is given.

- Annals (ed. 1615), p. 748. 
Brentwood by the 27th of that month, whilst 22,000 foot soldiers had been ordered to be at Stratford-le-Bow by the 29th. ${ }^{1}$ On or about the 22nd, Leicester was appointed formally to the command of the camp. The title conferred upon him was that of 'Lieutenant and Captain-General of the Queen's Armies and Companies ', but he was generally spoken of as 'the Queen's Lieutenant ', or ' the Lord Steward ', or ' the Lord General'. In spite of the ample powers suggested by his imposing title, he seems to have been given no authority over any of the queen's forces except those actually in the camp itself. On the 24th, he wrote from Gravesend to the privy council acknowledging and returning thanks for his appointment. ${ }^{3}$ He added that he had been very much comforted by words the queen had spoken to him before his departure from London, and that he had taken care to blaze them abroad.

There is evidence that, for a time, considerable confusion reigned in the camp, owing to the queen's delay and parsimony in providing military necessaries and the unavoidable haste in which the troops had had to be brought together. Thus, on the 25th, Leicester himself had to ride across country to Chelmsford, in order to arrange for 4,000 Essex men, there assembled, to proceed to the camp. He reports in a letter he wrote to Walsingham on that day from Chelmsford that he was returning to Tilbury that evening." Down to this time he appears to have been by no means happy in his position, heving (he thought) too few officers under him to maintain properly the dignity of his office. He reported to Walsingham (no doubt in part humorously) that he had even to act as his own cook and caterer. Doubtless he felt easier in mind next day, when the Essex men arrived at the camp, as he reports in one of his many letters to Walsingham. ${ }^{5}$

They be [he says] as forward men, and all [as] willing to meet with the enemy, as ever I saw; but, [owing to their sudden departure, they had] brought not so much as one meal's provision of victual with them; so that, at their arrival here, there was not a barrel of beer nor loaf of bread for them-enough [he continues], after 20 miles march, to have been discouraged and to have mutinied; but all, with one voice, finding it to be [due to] the speediness of their coming, said they would abide more hunger than this to serve her Majesty and the Country.

Leicester at once sent out victualling parties to scour the whole of the surrounding country for provisions and drink. Further, on the 26th, he sent off a letter addressed to the officer in charge of a party of a thousand London troops, then on the march to

\footnotetext{
1 Seo Bruce's Report, Appendix xrx.

- Seo Acts of the Pricy Council, sri.

- State Papers Domestic, Eliz., cexiii, no. 21.

- Ibid. coriii, no. 22.
}

- Ibid. coriii, no. 32. 
Tilbury, ordering a halt wherever his letter might chance to meet them, 'except they had provisions with them '.1 It was not till the 30th that the privy council wrote to the lord mayor, ${ }^{8}$ informing him that-

there were a greate number of soldiers assembled in the counties of Essex and Kent, under the charge of the Lord Steward her Majestye's Lieutenant against Foreign Invasion; [and] forasmuch as their Lordships thought they might lacke drynke, [their Lordships asked the Lord Mayor] that he would sende for the beere brewers and others occupying the trade of conveying beere to and fro, that they would carrye some quantity of beere thither, where they should finde readie moneye.

No doubt the arrival of the Essex men was followed quickly by the advent of other troops and other officers, causing the lord general's spirits to rise rapidly. Among others came Lord Grey, who on the 28th had been appointed 'Lord Marshall' of the camp. $^{3}$

Nor were the measures taken at Tilbury to ensure the defence of London confined to the formation of this camp ; for an attempt was made to block the Thames, and thus to prevent the passage of the Spanish ships up towards London, by stretching a boom across the river, from Tilbury to Gravesend. This was a very substantial affair, constructed of chains and ship's cables, and stiffened by means of ship's masts and anchored lighters. Even before it was finished it was estimated to have cost over $£ 2,000$."

Thus, arrangements at the camp were being brought rapidly into order, and Leicester evidently thought that the time had come for a new move on his part. Accordingly, on the 27th, he wrote to the queen inviting her to pay a visit to the camp. ${ }^{5}$ At the same time (inasmuch as the fate of the Armada was still unknown), he advised her majesty strongly not to go near any part of the coast, where her person might be in danger of capture by some landing party; but, he adds,

This farr, yf yt please you, you may dare :- to draw your self to your house at Havering and your army being about Iondon (at Stratford, Eastham, Hackney, and the vyllages thereabout), shall be always not only a defense, but a reddy supply to these countreys, Essex and Kent, yf nede be ; and, in the meane tyme, your Majestie, to comfort this army and [the] people of both these countreys, may, yf it please you, spend ij or iij [days] to se both the Camp and the forts. Hit ys not above xiij myle at most from Havering and a very convenyent place for your Majestie to lye in by the way and to rest ye at the camp. I trust you wylbe pleased with your pore

I State Papers Dom., Eliz., ccxiii, no. 38.

- Acts of the Privy Council, xvi, pp. 204-5.

3 Ibid. xvi. 196 and 197. Apparently this was Lord Grey de Wilton (succeded 1562, diod 1593).

- State Papers Dom., Eliz., cexii, no. 78, and cexiii, no. 9.

- Ibid. cexii, no. 46. 
lyvtentes cabyn ; ${ }^{1}$ and, with in a myle, there ys a gentleman's howse, where your Majestie may also lye. [By coming,] you shall comfort not only these thousands but [also] many more that shall hear of yt.

And thus farr, but no furder, can I consent to adventure your person; and, by the grace of God, there can be no danger in this, though the enymye should pass your flete; but your Majestie may without [harm] return to your owne forces, being but at hand; and you may bave 2,000 horse well to be loged at Romford and other vyllages near Havering and your foot men may loge nearer London.

Apparently the queen approved Leicester's suggestion-at all events in the main-and wrote to him saying so. Yet nearly ten days passed before arrangements could be completed for the queen to visit the camp. On 5th August Leicester wrote to her again-this time from the camp itself :-2

My moost gratious la[dy]-I have recesved in secrett this morning those newes that pleaseth me most, next [after] the assurance of the welldoing of your sacred person; which ys that your Majestie doth intend to beholde the pore and base compayne that lye here in the fyld most wyllingly to serve you-yea, most reddy to dye for you. You shall (dear lad[dy]) behold as goodly, as loyall, and as able, men as any prince chrystian can shewe you, and yet but an handfull of your owne in comparyeon of the. rest you have. What comfort not only these shall receav who shalbe the happiest to behold your self, I can not express; but assuredly hit wyll gyve no smale comfort to the rest. ...

Good sweet Q[ueen], alter not your purpose iff God gyve ye good health. Hit wyll be your payne for the tyme, but your pleasure to behold such people; and surely the place, I know, must content you, being as fayre a soyle and goodly a prospect as may be sene or found, as this extreme wether hath made tryall, which doth vs lytle anoyance, hit ys so fyrm and drye a ground. Your usher ${ }^{3}$ also lyketh your loging, a proper swete clenly house, your camp with in a lytle mylle of you, and your person to be as sure ae at St. James, for my lyfe : only we had a myshapp of a landing place, whear hoys \& boats had somewhat broken the bridge ; but all to be repared fully by to-morrow night early, agenst the next day, to doe you servyce :' God grant it so to be. You shall make glad many thousands, both here and not fsrr of, and shall se your soldyers, rather of a yeres experyence then of a months camping.

God bless your Najestie and make us all happy by your long lyfe.

Your Majestie, most bound vassel

R. Leicester.

1 He means, of course, his own quarters at or near the camp.

- State Papers Dom., Eliz., xxxiv, no. 34. The letter is dated ' Jth July', clearly a slip for 5th August.

'The official known as 'The Queen's Usher' was charged with the duty of preparing for her reception any house in which it was intended she should stay, whilst on progress or otherwise.

- That would be the 7 August, the day on which no doubt the queen had written to asy she expectel to reach Tilbury. As a matter of fact, she did not arrive until the 8 th. 
The arrival of this letter in London seems to have raised doubts as to the wisdom of Leicester's proposal ; for next day Walsingham wrote to Leicester a letter ${ }^{1}$ which he sent from court by the hand of 'a trustie messenger', who (he says) would tell him 'what we like of the Queen's repaire to the Camp, ... and what dowtes are made of mysadventure that may fall out'. Nevertheless, he adds, 'I meane to steale to the Campe when her Majestie shall be there'.

It will be noted that, in his second letter to the queen, Leicester makes no reference to the proposal, made in his earlier letter, that she should establish herself at her palace at Havering and should proceed thence by road to the camp. As a matter of fact, this part of his plan had been dropped ; for, on 8th August, the queen proceeded to the camp by water, probably from Westminster, landing about mid-day at the blockhouse, which stood where Tilbury Fort now stands. 2 This fact and all the chief events of the queen's visit to Tilbury are related in some detail by at least two contemporary chroniclers. One was James Aske, already mentioned, about whom I have been unable to learn anything. ${ }^{3}$ Clearly, he was present at the camp (very likely as a soldier) during the queen's visit, the events of which he narrates in a long versified narrative entitled Elizabetha Triumphans. In his 'Address to the Gentle Reader', he refers to it as 'my first worke, with myself a yong versifyer'. He says also that it was ' both begun and finished very neere within the space of one whole moneth, [but that] I was afterwards three long moneths studying whether it were better for me to burne it or to give it to the presse'. To have destroyed it would have been a pity ; for it is of interest as a record, in spite of its tedious and verbose style. The other writer was Thomas Deloney, well known at the time as a writer of ballads, pamphlets, and the like." His poetical account of the queen's visit ${ }^{5}$ is much shorter than Aske's, but of greater literary merit. Unfortunately Deloney's poem contains

1 Printed by Wright, Elizabeth and her Times, ii. 384 (1838).

- Misa Striokland's statemont (Lives of the Queens of England, iv. 675, 1851) that she came by rosd, vis Havering, is, therefore, wrong.

- Possibly ho was identical with a certain James Askew, citizen and stationer, who was esocisted with the Stationers' Company about this time. In 1590 he was admitted into the livery, paying 20s. therefore; in 1589 he took an epprentice and, in 1593, another; and, in 1590 , he paid a fine for not serving as Junior Warden : reo Arber's Transcript of the Company's Regisiers.

- Deloney was born about 1043 and died about 1600 . Originally a silk-weaver, he became a writer of considerable fame. A collected edition of his works, edited by F. O. Mann, has boen published (1912).

- The Quean's visiting of the Campe at Tilsturie, with her Enterlainement there. Printod by John Wolf for Edward White, 1588. It was ontered for copyright at Stationers' Hall, 10 August 1588 (éber's Tranecript, ii. 231, 1875). There is a anique (broadgide) copy in tho Britigh Museum. It was reprinted by J. O. Halliwell in 1860 ; by E. Arber in 1895 (English Garland, vol. vii), and by F. 0.3 Mann in 1912. 
internal evidence that its writer had not been an eye-witness of the events he narrates. Thus he speaks of 'Tilsbury' instead of Tilbury, though this might be a printer's error. Further, he says the queen landed at Gravesend and continued on horseback to the camp-a strange proceeding, unless she rode a sea-horse. There is, indeed, in all Deloney's 190 lines, no information which he might not have derived by hearsay from someone who was present. Nevertheless, his poem is well written, readable, and apparently trustworthy. Aske's and Deloney's productions, taken together, afford a fairly complete account of the doings at the camp during the queen's visit.

From what Aske and others tell us, we are able to define with some precision the position of the camp. This was not at Purfleet, in the parish of West Thurrock, as is often stated, but some seven miles further west, in the parish of West Tilbury. Even so, it was not (as might be supposed) actually on the bank of the Thames, near the blockhouse (on the site of which Tilbury Fort now stands). Nor was it on the low marshy flats stretching northwards for over a mile and a half from the river's bank to the foot of the bold escarpment which here forms the northern boundary of the Thames valley. This is divided by small valleys into more or less steep and well-defined hills; and the Camp Royal (or, at all events, the chief portion of it) was pitched on the summit of the most striking of these hills-that (about 150 feet) on which stand West Tilbury Church and Hall. This hill is re. markable, not from its height (which is small, as stated), but by reason of the steepness of its sides, which rise more or less abruptly from the low flat marshland, with no greater elevation anywhere in the vicinity to afford a contrast. Consequently the view from its summit, both up and down the river valley, is fine and extensive. As Aske's lines (quoted hereafter) amply show, it excited the admiration of all those assembled in the camp. Leicester himself thought it, as we have seen, 'as goodly a prospect as may be seen or found '.

A clear, though very diminutive, view of the hill and camp, with tents standing and flags flying, is shown on a contemporary chart of the Thames, by Robert Adam, ${ }^{1}$ said to have formed the original of one of the tapestries depicting the fate of the Armoda, which formerly hung in the House of Lords. Distinct traces of an earthwork, enclosing some four or five acres, may be seen to this day, surrounding the hill-top and enclosing the church and hall. ${ }^{2}$ They are most obvious on the southern face

1 Reproduced in Pine and Morant's Tapestries in the House of Lords (1739), also in Bruoo's Report (1798), facing p. 32.

- The Rov. W. Holman, an Easex historian who froto about 1715, taye (MSS. at Colohester Cartle) : "Twas where the windmill now stands. Some restigia of it are VOL. XXXIV. - NO. OXXXIII. 
of the hill, just at the back of the hall. It has been generally assumed that these very slight banks and ditches, now much obscured by gravel digging, are remains of Leicester's camp ; but it is in every way probable that they are many centuries earlier than his time. The position is one to which early man would inevitably have been attracted on account of its defensive possibilities ; for the hill is not only steep on all sides, especially on the south and west, but it is connected with the high ground at the back (that is, on the north) by a narrow natural causeway, two or three hundred yards long, which itself has fairly steep sides, especially on the west. The configuration of the ground here is decidedly unusual for the neighbourhood. ${ }^{1}$ However this may be, it seems certain that Leicester's camp extended inland (northwards) for some distance from Tilbury Hill ; for, according to local tradition, part, at any rate, of the camp was pitched in a field at Biggen Heath, nearly two miles north. ${ }^{2}$ Anyway, it would be hard to find anywhere a healthier camp-site; for the soil of the vicinity is sandy and gravelly, forming that 'firme and dry ground' of which Leicester had spoken in his letter to the queen. In regard to what would now be called its strategic importance, we have Leicester's opinion ${ }^{3}$ that it was 'very good ground for aptness for the defence of this coast'.

The troops assembled in the camp seem never to have been very numerous. Aske declares that

\section{A Camp of fiftie thoussind able men}

Appointed should have layne on Tilbery hill.

But, whatever the intention may have been, nothing like so large a force was ever assembled in the camp. A later return shows ${ }^{5}$ that there were no more than two thousand horse, under the earl of Essex, as master of the horse, and eighteen thousand foot, under Sir Thomas Layton. Sir Francis Knowles was master of the ordnance, according to Aske, who gives the names of many other officers. More troops were, however, stationed near at hand, especially on the other bank of the river, near Gravesend-no doubt to protect the further end of the boom. Deloney, after describing and praising the camp, declares that,

still remaining.' See also Camden (Britannia, Gough's 2nd ed, ii. 130, 1806); I. Chalkley Gould (Vict. County Hist., Easex, i. 306, 1903); and many modern topographers.

1 Mr. F. C. J. Spurrell arys (Archaeol. Journ., xlii. 296, 1885) that ' the aquare work which was constructed when Elizabeth rested at West Tilbury during her progress of inspection to Tilbury Fort still remains little altered'. But of the whereabouts of this work I can hear nothing.

- Cannon-bells dug up midway between these two extremes are in the possession of the Rev. Edrard Smith, rector of Chadwell St. Mary.

- State Papers Dom., Eliz, coxiii, no. 38.

- Elizabetha Triumphans, p. 15.

- Acts of Prity Council, rvi. 222. 
To see a sight so strange in England,

'twas our Gracious Queen's intent;

And, on the eight of August, she

from faire St. James' tooke her way,

With many Lords of high degree, in princely robes and rich aray;

And to bardge upon the water

(being King Henryes royall daughter !)

She did goe, with trumpets sounding

and with dubbing drums, apace

Along the Thames (that famous river), for to view the Campe a space.

Here Aske (who, it will be remembered, was probably in the camp already) takes up the narrative. He tells how, on the morning of the day in question, all arrangements for the queen's reception having been made, the earl of Leicester and his principal officers-

At water-side within the Block-house stayd,

In readinesse there to receive our Queen;

Who, landed now, doth passe along her way;

She, thence some way, still marching King-like on,

The cannons at the Block-house were discharged;

The drums do sound, the phifes do yield their notes,

And ensignes are displayed throughout the Campe.

Our peerlesse Queene doth by her souldiers passe,

And shews herself unto her subjects there.

She thanks them oft for their (of dutie) paines,

And they again on knees do pray for her.

They coutch their pikes and bowe theire ensignes downe

When as their sacred royall Queene past by,

In token of their loyall beared hearts

To her alone, and none but only she.

On the way from the blockhouse to the camp, across the low flat marshland, the queen is met by an escort of 1,000 horse, under Sir Roger Williams, and 2,000 foot. At this point Deloney comes in again. He tells how
All the way her Grace was riding, on each side stood armed men,
With muskets, pikes, \& good caleevers, for her Grace's safegarde then.

With her rode the Lord General and the Lord Marshall, each with his flag borne before him. As the queen proceeded (says Deloney), the soldiers lining the two sides of the road fell upon their knees and cried out blessings upon her. This they did so loudly that (however much her inordinate vanity may have been flattered) 
she felt bound to send messengers on ahead to bid the soldiers not to pay her such idolatrous reverence. Approaching the camp itself (continues Deloney), the queen,

casting up her princely eyes

unto the hill, with perfect sight,

The ground all covered (she espyes)

with feet of armed souldiers bright ;

Whereat her royall hart so leaped on her feet upright she stepped,

Tossing up her plume of feathers to them all, as they did stand :

Chearefully her body bending, waving of her royall hand.

Thus, through the Campe she passed quite, in manner as I have declared.

At Maister Riches, for that night, her Grace's lodging was preparde.

Aske says that the queen, having inspected the whole of her assembled forces, passed,

From out the Campe unto her lodging then,

Full three miles distant from that warlike place,

Prepared for her, to Maister Ritche his house,

With purpose meant for to returne next day

That way againe, the better it to view.

There is ample evidence that 'Maister Ritche his house' was Arderne Hall, in Horndon-on-the-Hill, and that this was the 'proper sweet cleanly house' which Leicester had recommended to the queen. His letter shows that it had been inspected and approved by the queen's usher, and there still exist two orders to the queen's treasurer to pay certain monies to Richard Blakenbury, as gentleman usher to the queen, and nine other of her majesty's servants, 'for preparing Maister Rych's House, in Essex', for the queen's occupation. The only thing which can throw any doubt upon the point is Leicester's statement that the house selected lay no more than 'a little mile' from the camp. As a matter of fact, Arderne Hall lay at least four miles from Leicester's head-quarters on Tilbury Hill. Even if a portion of the camp extended as far northward as Biggen Heath, one could still scarcely say that the house lay within three miles of the camp. Possibly when Leicester wrote his letter to the queen a fortnight earlier, he had in view some other house, afterwards discarded; or, possibly, he used the term 'a little mile', not literally, but as meaning merely 'a short distance'. 
However this may have been, Arderne Hall was a house of no great size or pretention. Norden does not even mention it in 1594 among the principal Essex houses. ${ }^{1}$ At the time of the queen's visit it belonged to one William Poley, though occupied by Thomas Rich, said to be connected with the family of Lord Rich. The house continued to exist until about the year 1730, when it was demolished and a solid square red-brick house was built on its site. This house still stands. A brew-house of timber, still standing at the back, is clearly of early Tudor age, and an adjacent dove-cote of brick is, apparently, almost as old.

At Arderne Hall, then, the queen passed the night of 8th-9th August. Aske tells us how, arrived at the house,

the Horsemen turned backe;

But all the rest, with her great Serjant, did

Watch there all night aloofe her royall Court.

The souldyers, which placed were farre off

From that same way through which she past along,

Did hollow oft 'The Lord preserve our Queene.'

He happy was that could but see hir Coatch,

The sides whereof, beset with Emmerods

And Diomonds, with sparkling Rubies red,

In chequer-wise, by strange invention,

With curious knots embroderd with golde. .

Aske (who seems to have been present) records the subjects discussed by them before they fell asleep :

Some praise the place whereat they camped are;

Some praise the disipline as used therein ;

And other some the passing forwardnesse

Of Noblemen and Gentels lyeing there.

But all of them do say the souldiers are

Mostly comely men, appointed well therto.

The following morning, the queen (as Aske tells us) returned to the camp-

Most bravely mounted on a stately steede

With trunchion in her hand (not used thereto), And with her none except her Lieutenant, Accompanied with the Lord Chamberlaine.

She came to take part in the chief event planned for her visit to Tilbury-a formal review of her troops. Deloney's account of the ceremony is the fullest we have, whether he actually witnessed it or not. He tells us that the lord general and the lord marshall

- Description of Essex (Camden Soc., 1840). 
went to meet her, and that together they conducted her in procession through the camp :

The Sergeant Trumpet, with his mace, and nyne with trumpets after him,

Bare headed, went before her Grace, in coates of searlet colour trim.

The King of Heralds, tall and comely; was the next in order duely,

With the famous Armes of England, wrought with rich imbroydered gold,

On finest velvet, blue and crimson, that for silver can be sold.

With maces of cleane beaten gold, the Queen's two Sargeants then did ride-

Most comely men for to behold, in velvet coates and chaines beside.

The Lord Generall then came riding, and Lord Marshall hard beside him.

Richly were they both attired, in princelie garments of great price ;

Bearing still their hats \& fethers in their hands, in comely wise.

Next came the queen, with four footmen walking on each side of her, attended by her ladies, her body-guard following. Meanwhile, the army, in full panoply, set itself in battle order for inspection. Says Deloney :

Such a battaile, pitcht in England, many a day had not been seene.

After this, the queen, taking her stand at a favourable point, watched a march-past of all the troops.

The warlike Armie then stood still, and drummers left their dubbing sound,

Because it was our Prince's will to ride about the Armie round.

Her Ladies she did leave behind her and her guarde which still did minde her.

The Lord Generall and Lord Marshall did conduct her to each place.

The pikes, the colours, and the lances, at her approach, fell downe apace.

Finally, the queen delivered her famous speech to the troops. That she really did address them seems certain ; for we have three independent reports of what she said. ${ }^{1}$ Yet all three differ widely.

1 The writer of the well-known letter to Mendoza (who claims to hare been present in the camp) savs, howerer, nothing of any speech. 
Aske (who probably heard the speech) gives, in twenty-seven lines, a version which he describes as

$$
\begin{aligned}
& \text { Her Royall Speech (though nothing like her Speech); } \\
& \text { Which, in effect, was it that here ensues. }
\end{aligned}
$$

Deloney (who probably wrote from hearsay) condenses it into nine lines only. The third version-that, in prose, which has long been current-is by far the fullest of the three, and is, in sentiment and diction, much superior to the others. As to its authenticity I know nothing ; for I have failed to discover when and by whom it was first published. It may have been prepared in advance for the queen to deliver, but it reads more like a report drawn up afterwards by some skilled literary hand. After the delivery of the speech, the assembled army, 'all at once, a mightie shout or crye did give'; and, while trumpets sounded, the queen rode away to the lord general's tent, wherein, at noon, she took dinner.

During the meal an important event occurred : the earl of Cumberland arrived at the camp with dispatches from the fleet, which he had left off Harwich on the 7th. ${ }^{1}$ No messenger ever arrived more opportunely. Down to that moment there had been no news as to what had happened to either the Spanish or the English fleet since the dispersal of the former in Calais roadstead on 28th July and its subsequent flight northward. Now the lord admiral reported in dispatches that he had pursued the Armada northwards until the 2nd August, when (being somewhere off the Firth of Forth) he had lost it, and being short of powder and shot, he had turned back south. He reported, further, that he expected to reach the Downs that same evening, the 8th. ${ }^{8}$ On the same day, Drake wrote to the queen from on board his ship, the Revenge, then lying in the Downs. ${ }^{3}$ He reported that, in his opinion, it was no longer possible for the Armada to return southward, by reason of its battered condition and the then prevailing winds; but he was obliged to confess that it had disappeared and that he knew not whither it had gone, though he thought it was probably making for Denmark, hoping to be able to refit there. ${ }^{4}$ He suggests to the queen that she should send a ship thither to investigate, and urges that, pending this ship's return, no diminution of defensive measures should be sanctioned. It was clear to all, therefore, that for the time being,

1 State Papers Dom., Eliz, ccxiv, no. 50.

- Ibid. ccriv, no. 42. Printod by Bruco (Report, p. cclsssvi, 1798), and by Laughton (Defeat of Spanish Armada, ii. 52-3, 1804).

- Ibid. cexiv, no. 47. Printed by Bruce (Report, 1788), by Laughton (Defeat of Spanish Armada, ii. 68), and by Wright (Elizabeth and her Times, ii. 385-6).

- The Lord Admiral expressed the same view in a letter to Walgingham dated oth (State Pepers Dom., Eliz, ccriv, no. 61). 
at any rate, the Armada was disposed of, and that England was no longer threatened with invasion; but how complete was the overthrow of the great fleet no one knew till weeks later, when news which came in by degrees showed that it had fled north about in an endeavour to return that way to Spain, and that a remnant of it had succeeded in so doing, after suffering every kind of disaster through storm, shipwreck, starvation, and sickness.

But the earl of Cumberland brought also other news of a less satisfactory kind-a report that the laggard duke of Parma had at last got ready his army, and that it was already embarked and on its way to invade England. The report spread rapidly. We find allusion to it in nearly all the State Papers and official correspondence of the next few days, together with anxious surmises as to where the force intended to attempt a landing in England. Young Edward Radclyffe, writing next day to his relative the earl of Sussex, says : ' 'Whilst her Majesty was at dinner in the Lord Generall's tent, there came a post and brought intelligence that the Duke, with all his forces, was embarkt for England'. Walsingham, writing on the same day, from the camp itself, gives full credence to the report. ${ }^{2}$ Two days later a professional newsletter writer wrote to a client ${ }^{3}$ : 'Our news on Friday was certain-that the Prince was embarked with 50,000 foot and 6,000 horse', and that he was expected to land in England at once, as the tides were then at their highest. In short, all the evidence goes to show that, for a few days, the report was generally credited. Ultimately it proved untrue; but, for the time being, it was suffioiently alarming.

As soon as the dispatches had been discussed; Mr. Secretary Walsingham (who had carried out his intention of stealing down to the camp whilst the queen was there) was busy writing letters to other officers of State, giving them the latest news, good and bad. Several which have been preserved are dated 'At the Court, in the Camp, this 9th August 1588'. One was to Lord Burghley ; another to the lord chancellor; and a third to the lord treasurer 4 The contents of all were to much the same effect; but, to that to Burghley, he added :

A conceit her Majesty had that, in honour, she could not return [to London], in case there were any likelihood that the enemy would attempt anything. Thus, your Iordship seeth that this place breedeth courage. I fear now more from the hand of God, in respect of unseasonableness of weather, than [from] the enemy.

1 Cotton MS., Otho. E., ix. fo. iso b.

2 Harl. MS. 6994, fo. 142 (printed by Laughton, Defeat of the Spanish Armada, ii. 82-3).

- Burghley Papera at Hatfield, Rep. of the Hist. MSS. Comm, iii. 346 (1889).

- Harl. MS. 6994, nos. 73, 74, and 76 (all printed in Langhton's Defeat of the Spaniah Armada, ii. 82-3, 1894). 
The queen's hesitation was due, no doubt, to the reported imminence of invasion by the army under the duke of Parma, and it was a natural feeling in the circumstances.

In the course of the afternoon, says Aske, ${ }^{1}$ the queen left the lord general's tent,

And passed thence unto the water side;

Where, once embarg'd, the roring cannons were

Discharged-both those which were on Tilb'rie Hill

And also those which at the Blockhouse were.

The events which followed immediately on the queen's departure recall the closing words of Walsingham's letter to Burghley, in which he refers to the badness of the weather, which had been extremely unsettled for some weeks. Seymour, who had put to sea early in July, scouting after the Armada, had written to Walsingham: 'Such summer season saw I never the like;' adding, 'I fynd no manner of difference between wynter and somer, saving that the daies be now longer'.8 Again, within the preceding three days the weather had been very threatening, as Leicester's letter of the 5th shows. Any way, immediately after the queen had left Tilbury in her barge, a violent thunderstorm broke. Aske says : ${ }^{3}$

And there, even then, the 'fore white-mantled ayre,

From whence the sunne shed forth his brightest beames,

Did clothe himselfe with dark and duskie hue,

And with thick clowdes bar'd Phoebus gladsome streames.

From lightning then the earthe with glorious shew.

It powres foorth showers in great and often droppes,

Signes of griefe for her departure thence;

And Terra now, her Highness foot-stoole late,

Refuseth quite those drops desired before

To moisten her dried up and parched parts,

And, of herselfe, even then, she yeelded foorth

Great store of waters from her late dried heart,

Nor deeply drowned, for this the parted losse

Of that her sacred and renowned Queene.

Later, Aske relates how Thames calmed his billows, ' raging sore before'; the thunder and lightning ceased; the violent wind fell; and the 'elements' became inore favourable. After this, Aske turns his attention abruptly to other matters.

There is abundant evidence that the queen's visit to the camp had an excellent effect on the spirits of the troops there. Leicester

1 Elizabetha Triumphans, p. 26.

- State Papers Dom., Eliz, ccrii, nos. 34 and 64.

- Elizabetha Triumphans, p. 26. 
himself says ${ }^{1}$ that the queen's visit 'so enflamed the harts of her good subjects as I think the weakest person amonges them is able to match the proudest Spaniard that dares land in England '. Two other contemporary writers testify to the same effect. Camden says ${ }^{2}$ that 'it was incredible . . how much shee strengthened the hearts of her captaines and souldiers by her presence and speech'. Stow declares ${ }^{3}$ that-

her presence and princely encouragement, Bellona-like, infused a second spirit of love, loyaltie, and resolution into every souldier in her Armie ; who, being (as it were) ravished with their Souveraygne's sight, that. [all] (a.s well Commanders as common souldiers) quite forgate the ficklenesse of fortune and the chance of Warre, and prayed heartily the Spanyards might land quickly; and, when they knew they were fled, they beganne to lament.

The last few words may seem to support the view which several writers of high repute have taken, that the queen's visit to the camp was mere theatrical display, inasmuch as she had deferred making it until the Armada had been defeated and all danger of invasion had passed. ${ }^{4}$ For such a charge there is absolutely no justification. It is true that the Armada had suffered irrevocable defeat over a week before, and that since then England had been no longer in any danger from it. But it is equally undeniable that down to the time of the queen's visit to the camp, no one in it, or in London, or elsewhere in southern England knew, or could have known, these facts. They were known, of course, to the lord admiral, to Sir Francis Drake, and to the other commanders on board the ships of the English fleet; but these were all away at sea and unable to convey the news apeedily to the authorities in London. It was (as we have seen) not until the very day of the queen's visit to the camp (and, indeed, whilst she was actually in it) that the great news first reached her and her officers of state. Even then, and for some days afterwards, there remained a doubt whether, although the Armada had been disposed of, an invasion might not still be attempted by the army assembled in Flanders under the duke of Parma-a doubt which was not finally set at rest until some days later.

Of the events connected with the queen's return journey from the camp to London, Aske says nothing-probsbly because he knew nothing. There is, however, some reason to think that, on this journey, something occurred which altered the arrange-

1 Letter written from the camp to the earl of Shrewsbury, 15 August, printed br Wright, Elizabeth and Her Times, ii. 391.

I Hist. of Queen Elizabeth, iii. 142 (1630, but written mach earlier).

3 Anrals (ed. 1615), p. 748.

- See Dict. of Nat. Biogr., svi. 119 ; and srii. 223 ; also Vict. County Hist., Essex, ii. 222 . 
ments. In the first place, it seems clear that the queen passed one night only at Arderne Hall, arriving on the 8th August and departing on the 9th. Yet there is some evidence that she spent two nights away from London-that of the 9th as well as that of the 8th. An entry in the accounts of the churchwardens of Lambeth, recording that they paid three shillings 'for ringing when the Queene's Majestie came from the Campe to St. James's', would have been of much interest in this connexion if it had been dated, but unfortunately it is not. If the queen really did spend a second night away from London, it remains to be shown where that night was peissed ; and there are some grounds for believing that it was passed in the mansion of Edward Barrett, esquire, of Belhus Park, in Aveley. A tradition that the queen visited Belhus on some occasion has long been prevalent locally, and it has generally been associated with the queen's visit to the camp at Tilbury. Nichols, writing nearly a century ago, ${ }^{1}$ in a very confused passage ascribed the reputed visit to the year 1578, apparently quoting from a contemporary letter, the present whereabouts of which is unknown; but the year 1588 seems much more likely. There are, indeed, sundry items of evidence leading one to think that the queen really did visit Belhus in connexion with her visit to the camp at Tilbury, though there is no actual proof ; and these scraps of evidence are quite independent of the tradition already mentioned.

It is known that the queen did not leave Tilbury until very late in the day. Deloney says that she delayed her departure until ' night approached nye'. It seems hardly likely she would have done this if she had intended to cover that night, first the two miles by road to the waterside and then the twenty-four more by rowing-barge to St. James's; but she might very well have done so if she intended to proceed that night no further than Belhus, only a few miles distant. Possibly a visit to Belhus had been arranged at the last moment, in order that the queen might remain a little longer in the vicinity of the camp, which (as mentioned already) she was reluctant to leave whilst any danger of invasion remained. This would at least explain her late departure. ${ }^{2}$ In any case, Belhus is connected in another way with the queen's visit to Tilbury ; for it seems certain that it must have been the 'gentleman's house' at which Leicester ${ }^{3}$ had suggested to the

1 Progresses of Queen Elizabeth, ii. 92-4 (1823).

- Another suggestion is that, when the queen left Tilbury, she intended, in epite of the lateness of the hour, to proced direct to London, but that, being overtaken by the tempest already mentioned, she landed at Purfleet (seven miles up-river) and proceeded overland (two miles and a helf) to Belhus, where she sought refuge from the storm and pased the night. This is pure surmise, bat by no means imptobable. Seo W. Palin, Stifford and its Neighbourhood, p. 106 (1872).

2 In his letter of 27 July (soe ante, p. 46). 
queen she might conveniently sleep when on her journey by land (then contemplated, but never undertaken) from her palace at Havering to the camp. There seems to be no other 'gentleman's house' which he can have had in mind. Certainly he cannot have meant Arderne Hall (at which the queen actually did sleep), for that house lies quite off the route she would have followed, whereas Belhus lies very close to it. ${ }^{1}$

On the day of the queen's visit to the camp, Walsingham, writing to Burghley, ${ }^{2}$ had cautiously suggested that 'It were not wise, until we see what will become of the Spanish Fleet, to disarm too fast, seeing that her Majesty is to fight for a Kingdom '. But the fate of the Armada soon became known, and the baselessness of the rumoured invasion by the duke of Parma had become apparent even earlier. By the 17th August, therefore-about a week after the queen's visit-it was thought safe to break up the camp. An additional reason for so doing lay in the fact that the harvest was ready and needed to be got in. Accordingly, on the date named, the privy council wrote to Leicester ${ }^{3}$ advising him that they thought it

not neadfull that the Campe under his Lordship's charge should be continued anie longer ; and, therefore, her [Majesty's] pleasure is that his Lordship should dismiss the companies, both horsemen and footmen, with thanckes and commendacions, both unto the parties themselves and also to be delivered unto such as sent them upp out of the shires.

A week later, on the 25th, the council also wrote letters direct to the lords-lieutenant of certain counties," 'signifying her Majestie's thanckes for their care in sending of hable and well furnished souldiers to the Camp at Tilburie, when they were latelie sent for'. Four days later the council issued orders ${ }^{5}$ for the return to store of all anchore, cordage, ropes, plank, \&c., used for the construction of the boom across the river; and during September

1 If the queen really did visit Belhus in 1588 , the fact would explain, to some extent, the tradition, locally prevalent and otherwise inexplicable, that the queen roviewed her troope and shipe at Purfleet and not at Tilbury. This tradition tells how the queen, ascending the eminence adjoining Porfleet, thence reviewed both camp and fleet, exclaiming 'Alas ! my poor Fleet', and that Purfleet thereby acquired its name. The legend is not altogether modern; for it is given by Holman, in his mana. soript collections, which were written about 1715 . Now it has been shown already that the camp was seven miles a way and that the fleet was at sea pursuing the Armada, so that the queen could not have reviewed either from the hill-top at Purfleet. Further, the nsme of the place was in regular use, in the form of 'Pourtfleet', centuries earlier. It aignifies the mouth of the emall 'fleet' or rivar-the Mardyke, as it is called nowwhich here runs into the Thames. The whole silly story is of interest only as an example of the imaginative method of explaining the origin of place-nemes. Local tradition also ssys that the queen slept in Tilbury Fort. The room she occupied is etill shown, as I am told, though the Fort was not built until a century later !

- Harl. 6994, fo. 140 (printed by Laughton, ii. 84).

- Acts of Privy Couneil, rvi. 239.

- Ibid. p. 249.

Ibid. p. 255. 
there were many orders in reference to the payment of wages and the like. ${ }^{1}$ The total outlay at, and in connexion with, the camp was ultimately computed at $£ 161,185 .{ }^{2}$

Finally, it was fitting that thanks should be returned publicly for the deliverance of the country from danger. Accordingly, on 3 November, the privy council wrote to the two archbishops desiring them 'to appoint some speciall day wherein all the realme might concurr in giving publique thankes unto God '. 3 In due course the churchwardens of Lambeth expended six pence 'for Ringinge, the xixth of November being commanded a Generall Festivall day ', and also six pence 'for ij Bookes of Prayer against the same Festivall day' ${ }^{4}$ Later, apparently on the 24th, a thanksgiving service, attended by the queen, was held in St. Paul's Cathedral, 5 when (unless the record is wrongly entered twice over) the Lambeth churchwardens expended eight pence more 'for ij Prayer Books of Thanksgiving for our safe delivery from the Spaniardes'.

Mitler Christy.

1 Acts of Privy Council, sri.. 276-8 and 286.

- Stato Papers Dom., Eliz, cclrxvii, no. 59. It is worth noting that, eleven years later, in 1509, when proparations were again in hand for defence against another expected Spanish invarion, it was again auggested that a camp should be established at Tilbary (see State Papere Dom., Eliz., cclorii, no. 1).

- Acts of Privy Council, rvi. 334.

- Lambeth Churchwarden's Accounts, 1588.

- State Papers Dom., Eliz., cervii, no. 38. 